\title{
Small Arms and Light Weapons Proliferation in Nigeria: Re-structuring National Security Architecture for Optimal Results
}

\author{
Anthony Abah Ebonyi, Ph.D \\ Department of Sociology, APIS-University of Abuja, Abuja, Nigeria
}

\begin{abstract}
The global community continues to grapple with Small Arms and Light Weapons (SALWs) proliferation and their use in many conflicts. This phenomenon portends grave danger to world peace and security. This study seeks to achieve three objectives namely, trace the causes of small arms and light weapons proliferation in Nigeria, examine the security implications of the availability of SALWs in the country, and make a case for restructuring of the current security architecture. The study employs the desktop research design and, using content analysis of secondary data, including journal articles, agency reports, and seminar/conference papers, argues that the implications of SALWs proliferation on the nation's security, such as terrorism, kidnapping, armed banditry, cattle rustling, are enormous and threaten the soul of the nation. It finds that porous borders, corruption, and globalization precipitate small arms and light weapons proliferation in Nigeria. It concludes that proliferation of SALWs is engendered by criminal networks operating in various shades and manners across Nigeria. Thus, to tackle the menace, the entire security architecture as currently composed should be re-structured by way of decentralisation and devolution of powers and authority to achieve optimal results.
\end{abstract}

Keywords: Architecture, National security, Nigeria, Light weapons, Small arms

\section{INTRODUCTION}

$\mathrm{S}^{\mathrm{n}}$ mall Arms and their proliferation generally is not a new phenomenon. However, the pattern, trend and consequences have been a major concern to the global community (Onuoha, 2012). The proliferation of arms became an enormous concern especially since after the Cold War and rivalry between the superpowers (Ola, 2018; Ayuba \& Okafor, 2015), when the left-over arms from that war were shipped to other countries of the world subsequently making their way to parts of Africa, to fuel proxy inter-state conflicts (Salihu \& Ozden, 2020). The arms, now in the hands of illegal arms dealers, security entrepreneurs, ethnic militia groups, private military companies, and local smugglers, are being employed for various old armed conflicts and to facilitate the emergence of new ones in Africa, leading to general insecurity and increased criminal violence (Mallam, 2014; Agbiboa, 2013). These small arms are the weapons being used today by various non-state actors in ethno-religious conflicts, insurgency, militancy, kidnapping, armed banditry, cattle rustling and arm robbery in many parts of Nigeria, especially in the south-south, north-west, northeast and central geopolitical zones (Onuoha, 2012).

Technological breakthroughs in recent times have brought about advancements in arms and weaponry technology resulting in smaller, more portable, and easy to operate systems which are capable of causing measured and graduated large-scale loss of lives (Small Arms Survey, 2011). These portable, easy to carry weapons and arms are generally referred to as small arms and light weapons (United Nations, 1997). Small Arms Survey (2011) statistics showed that globally, there are approximately 875 million small arms in circulation, stockpile and private possession, produced by more than 1,000 companies from nearly 100 countries, and authorised trade exceeds 8.5 Million US Dollars (as cited in Chelule, 2014). 200 million belong to the government and State militaries, 26 million are in the hands of law enforcement agencies. However, the bulk of global small arms and light weapons, which is estimated at two third are held by civilians and non-state actors, and 100 million are reported to be in Africa (Chelule, 2014). This being the case, it is little wonder that Ali Mazrui, stated unequivocally, that "in a technologically underdeveloped society, in the twentieth century, ultimate power resides not in those who control means of production [as postulated by Marx], but in those who control the means of destruction [captured by the soldier/bandit with an AK47]"'(Chelule, 2014). The United Nations Security Council acknowledges the devastating consequences of SALW when it stated in its 2015 resolution that "illicit transfer, destabilising accumulation, and misuse of small arms and light weapons in many regions of the world, continue to pose threats to international peace and security, cause significant loss of life, and contribute to instability and insecurity" (as cited in Iloani and Sunday, 2016).

The proliferation of small arms and light weapons in Nigeria is a fallout of not just the armed conflicts in the global arena, including Africa and sub-Saharan Africa, but also a result of poor governance and the failure of governments in this regions to genuinely and holistically address the continuous issues of underdevelopment and low standard of living of the people (Chuma-Okoro, n,d; Ayissi \& Sall, 2005; Ayuba \& Okafor, 2015, Small Arms and Light Weapons: Africa, n.d). This is because arms trade is usually carried out by idle minds and hands - who of course need to survive by either hook or 
crook - who serve as either middle-men or carriers of these arms to the desired destinations. The situation is further exacerbated by the fact that small arms and light weapons would always have ready markets since the very conditions poverty, joblessness, hunger and starvation, greed, and general lack - that triggered the previous conflicts or wars are still with humanity, and will continue to remain so if arms and legs remain folded and crossed, and nothing concrete is done to reverse the trend. Some scholars (Agbiboa, 2013; Mallam, 2014, Thomas \& Aghedo, 2014) have examined the impact of SALWs on national security and the failure of the current security architecture to address the menace, but fell short of proffering an alternative security architecture that would effectively tackle the myriad of security challenges facing the country. This paper, therefore, attempts to fill the gap by examining the causes of SALWs and the challenges and threats they pose to the security of the Nigerian State, and to make a case for a re-structuring of the country's Security architecture for optimal results.

\section{CONCEPTUAL EXPLICATIONS}

\subsection{Security}

Attempts to have a holistic definition of security are best described as a trivial exercise because of its multifaceted nature (Mesjasz, 2004; Boemcken and Schetter, 2009). Security generally refers to the absence of threat to acquired values or freedom from danger. Buzan posited that security (from realist perspective) is taken to be about the pursuit of freedom from threat and the ability of states and societies to maintain their independent identity and their functional integrity against forces of change, which they see as hostile (Buzan, 1991). Buzan's conception of security assumes that security is the primary obligation of a state, in which force is the dominant tool for quelling dissent or threats to sovereignty or statehood.

However, the concept of security can be gleaned from its traditional meaning of the absence of military threat to the corporate existence of a state; which arises from inter-state relations; to security in a universal sense of human security (Nwolise, 2008). This concept of security is backed by the United Nations, where it stated in its Human Development Report that "The realist concept of security must change from an exclusive stress on national security to a much greater stress on people's security, from security through armaments to security through human development, from territorial security to food, employment and environmental security" (Human Development Report 1994). The same report has listed and explained several types or components of security - specifically human security - as the bedrock for all other securities. Furthermore, the core of security is captured by Baldwin (1997) as "a low probability of damage to acquired values", and "the absence of acute threats to the minimal acceptable levels of the basic values that people consider essential to its survival" (as cited in Boemcken and Schetter, 2009).
Buzan's definition of security emphasized two aspects of security, namely 'identity' and 'integrity' that were absent in the traditional realist and neo-realist conception of security. The current approach to security recognizes the "feeling of the people or the society of being secure or insecure". The concept of security has also been defined from an African perspective as "an all-encompassing condition in which people and communities live in freedom, peace and safety, participate fully in the governance of their countries, enjoy the protection of fundamental rights, have access to the resources and basic necessities of life, and inhabit an environment which is not detrimental to their health and wellbeing" (OECD, 2001). This implies that human security is intrinsically linked to state security and vice-versa. Overall, security as viewed from the social constructivism perspective engages various actors in a symbiotic relationship of social values and identities influencing these relationships. Thus, security is inter-subjective comprising a process of interaction and negotiation among collective social institutions (Karacasulu \& Uzgoren, 2007).

\subsection{National security}

National security is used in this paper interchangeably with internal security. Buzan conceptualises national security as constituting the three pillars of the state, that is, "the state's physical base in terms of territory and population; its institutions; and the shared idea of the state among its citizens" (Buzan, 1991). Therefore, national security is viewed as the acknowledgement and management of conditions that could violate these three pillars. The 'conditions' are many and vary across different geographic and geo-political territories, and include but not limited to actor-based - insurgency, terrorism, and other armed conflicts - and non-actor based - HIV/AIDS, Ebola, Polio, Tuberculosis, and other diseases (Sjostedt, 2010). Holmes (2015) argues that national security entails safeguarding the entire nation, but most importantly protecting its people from attack and external dangers by maintain the armed forces and guarding of state secrets.

National security encompasses much more than protection against internal and/or external aggression as the traditional security paradigm (involving military response and management of threat) postulates. Present-day realities and events, hinged upon natural and man-made threats such as hunger, unemployment, poverty, environmental setbacks, among others, in varying degrees, indicate that the old postulations hold no water and lack universal appeal. This informed McNamara, Nwolise, Abolurin, and others, to express this caution: "Any society that seeks to attain adequate military security against the background of acute paucity of food, population explosion, low level of production, low per capital income, low technological development, inadequate and insufficient public utilities and chronic problem of unemployment has a false sense of security" (as cited in Afolabi, 2016). Emphasising further, Nwolise, Abolurin, averred "A country may have the best 
armed forces in terms of training and equipment, the most efficient police force, the most efficient custom men, the most active secret agents and best quality prisons, but yet be the most insecure nation in the world as a result of defence and security problems within bad governments, alienated and suffering masses, ignorance, hunger, unemployment or even activities [sic] foreign residents or companies" (as cited in Afolabi, 2016). This means, therefore, that national security concerns steps taken to secure or protect national territory or sovereignty and infrastructure as well as provide basic human needs and guaranty the good life of citizens (as provided by the UNDP report on human security) located anywhere within a given nation.

Paris (2001) notes that human security - a more nuanced and broader conceptualization of security - came into prominence when, in the year 1994, the Human Development Report of the United Nations Development Programme (UNDP), stated that "The concept of security has for too long been interpreted narrowly "as security of territory from external aggression, or as protection of national interests in foreign policy or as global security from the threats of nuclear holocaust....Forgotten were the legitimate concerns of ordinary people who sought security in their daily lives." Paris was quick to add that this critique even while been "clear and forceful", lacks precision in its latter articulation for a new concept of security (human security). The report postulates: "Human security can be said to have two main aspects. It means, first, safety from such chronic threats as hunger, disease and repression. And second, it means protection from sudden and hurtful disruptions in the patterns of daily lifewhether in homes, in jobs or in communities."

\subsection{Small Arms and Light Weapons}

Small Arms and Light Weapons have been conceptualised and contextualised differently by different stakeholders including academics as covering a broad spectrum of weapons, their ammunitions and their spare parts. One definition by the ECOWAS Convention on Small Arms and Light Weapons, their Ammunition and other Related Materials of 2006, explains that small arms are arms destined for personal use including firearms and other destructive arms or devices such as an exploding bomb, an incendiary bomb or a gas bomb, a grenade, a rocket launcher, a missile, a missile system or a mine. Others include revolvers and pistols with automatic loading, rifles and carbines, machine guns, assault rifles and light machine guns. Light weapons in particular are portable grenade launchers, mobile or mounted portable anti-aircraft cannons, portable anti-aircraft missile launchers, mortars with a caliber of less than 100 milimetres (Okeke \& Orji, 2014).

Additionally, the United Nations General Assembly defines SALWs as any portable lethal weapon that expels or launches, is designed to expel or launch, or may be readily converted to expel or launch a shot, bullet or projectile by the action or an explosive (as cited in Chelule, 2014). Similarly, the United Nations Institute for Disarmament Research describes small arms to include these: revolvers and self-loading pistols, rifles and carbines, sub-machine-guns, assault rifles, light machinegun, heavy machine-guns, hand-held under-barrel and mounted grenade launchers, portable anti-craft guns, portable anti-tank guns, recoilless rifles, portable launchers of anti-tank missiles and rocket systems, portable launchers of anti-aircraft missiles systems, and mortars of calibers less than $100 \mathrm{~m}$ (as cited in Chelule, 2014). According to Emmanuel (2005),"the proliferation of small arms and light weapons, rifles, handguns, machine guns, grenades and bazookas - is just as harmful as the increasing number of so-called weapons of mass destruction." Citing Louse, he observed further that, light weapons used in a generic sense, refers to all conventional munitions that could be conveyed by an individual combatant or by a light vehicle including small arms such as bazookas, rocket propelled grenades, light antitank missiles, light mortars, shoulder-fire anti-aircraft missiles and hand placed landmines, as well as automatic weapons, up to, and including $20 \mathrm{~mm}$ such as sub-machine guns, rifles, carbines, and hand-guns (Jekada, 2005). Some of these weapons are known to have been carried by one armed group or the other in Nigeria, especially in the last decade, to perpetrate all sorts of heinous crimes.

\section{SECURITY CONSTRUCT}

Small and light weapons proliferation are threats to the security and corporate existence of any nation, hence, the need to establish a comprehensive and concrete national security architecture that can withstand the test of time in an increasingly global security uncertainties that currently constitute enormous challenges to world peace and human development.

There are two basic security paradigms, traditional and contemporary. The traditional security construct or traction views security mainly from a state-centric perspective whereby the state devotes a large chuck of her national budget to the security sector for the purposes of protecting the state against external aggressors, such as was the case with USA and Russia in the cold war era. However, as Paris notes, the field of security has moved passed its narrow traditional focus on the military might especially by state actors, to a broad focus on non-military security threats, which cares about the security of individuals and groups in terms of their socioeconomic, health, and environmental needs (Paris, 2001).

The question arises as to whether focusing on national security alone is sufficient to keep a state and its people safe and secured, and whether the human security component should be de-emphasized or paid less attention. Perhaps the long negligence of the human security aspect of security over time has necessitated the myriad security challenges that currently confront most parts of the globe, especially the African continent, where Nigeria as it stands now, is battling with all forms of security threats beginning from availability of SALWs across all the regions of the country, to banditry, 
herders-farmers clashes, terrorism/insurgency, militancy, kidnapping, armed robbery, amongst others; a situation that seems to have defied all workable solutions with increasing waves of crime and criminality.

The blame for the heightened insecurity situation in Nigeria has been placed at the front door of the government that almost always focuses on national security alone as opposed to human security and national security combined, to achieve optimal results in terms of engendering peaceful co-existence among all the different ethnic nationalities.

\section{CAUSES OF SMALL ARMS AND LIGHT WEAPONS (SALWS) PROLIFERATION}

There are several causes of SALWs proliferation in Nigeria, such as a general lack of transparency around the arms trade that tends to shroud the whole arms polices of Sub-Saharan African states in secrecy, the involvement of some of the states in illegal arms trade with corrupt arm dealers, as well as widespread insecurity that makes it easy for small arms to enter illicit circulation through theft, leakage or re-sale (Jacob, Ishaya \& Ado, 2019). Similarly, SALWs are characteristically attractive to security agents and civilians who like to use them, thus facilitating their proliferation. Furthermore, available data have shown SALWs are plentiful, cheap and durable and are weapons that are highly needed as profitable commodity that can be sold with little domestic and international regulation by different weapons producers or manufacturers (Boutwell and Klare, 2001; Jekada, 2005).

Underpinning the proliferation of SALWs in Africa generally and Nigeria in particular, is bad governance, high levels of poverty, struggle for scarce resources, and the competition for economic and/or political power among the elites, oil theft, money laundering, corruption, exploitation, terrorism, militancy, ethno-religious violence, scrambling for resource control, and other premeditated violence (Orji, 2014; Small Arms Survey, 2011; Onuoha, 2012; Abdullahi, 2015). Iloani \& Sunday (2016) writing in the Daily Trust Newspaper, observed that illegal arms were flooding Nigeria, and fueling different kinds of violence including cattle rustling, armed robbery, and cultism. The noted that even the deadly Boko Haram perpetrate violence using illegal arms, which supply they never lacked. The question is, what causes SALWs proliferation in the region?

There are several structural factors contributing to the proliferation of SALWs in Nigeria. They include but not limited to issues of governance, porous borders, globalisation, and corruption.

\subsection{Issues of Governance}

Poor governance and inability of government to provide needed security is a factor that compel the Nigerian citizens to look for alternatives (Onuoha, 2012). Studies by the Small Arms Survey (2011) indicate that lack of confidence in security forces, understaffing or sometimes simply the inability of security agencies to carry out their duty effectively in many African countries informs the need for citizens to acquire arms in order to protect themselves and their property from armed violence. For example, a research conducted in Côte d'Ivoire in 2010 shows that, contrary to common assumptions, state security providers do not perform much better than the rebels. Across Côte d'Ivoire, the population lacks confidence in its security forces. The report indicates that the deficiencies of the security forces combined with the level of insecurity have encouraged the emergence of a wide range of coping mechanisms, including community selfdefence and vigilante groups, which in turn create new forms of insecurity (Small Arms Survey, 2011).

Similar scenarios play out in Nigeria where, according to Onuoha (2012), politics and politicking is crude; stakes are incredibly high, thereby leading politician to resort to the use of violence via "specialist of violence" (cultists, gangs and thugs) in desperate move to win elections. He blames the overbearing influence of SALWs and the prevalence of violence on the failure of government to provide the basic necessities of life, effective, just and equitable sharing of resources and promotion of human security. This apparent weakness in governance has paved the way for frustrated and deprived teaming population of Nigerians to resort to all sorts of criminal activities including insurgency, militancy, kidnapping, armed robbery, among others, thus, heightening the demand for arms, their influx and proliferation (Gowfan, Ishaya and Ado, 2019; Onuoha, 2012).

\subsection{Porous Border/Cross-Border Smuggling}

In addition to the failure of governance, there is the porous nature of Nigeria's border that has strategically (even though sadly) positioned the country as 'dumping ground' for all kinds of consumable and non-consumable, legal and illegal or contraband goods from Western, Asian, Arabian and African countries. There is no denying the fact that, among some of these wholesome and unwholesome items, are SALWs carefully concealed and transported through porous borders of Nigeria. Theses arms later spread to all the geo-political regions of the country particularly the north-east, where they are being used by criminal elements of the likes of Boko Haram, to perpetrate mayhem on hapless Nigerians (Onuoha, 2012; Gowfan, Ishaya \& Ado, 2019; Salihu \& Ozden, 2020). On this score, Chuma-Okoro (2013) notes that because Nigeria shares a long stretch of land border with several African countries including the Republic of Niger and Chad in the North, Benin Republic in the West, and Cameroon in the East, as well as a long stretch of Atlantic coastline it makes cross-border smuggling of illicit arms into the country easy. He further argued that each of these frontiers notably the Idiroko and Seme land borders in the South-Western States of Lagos and Ogun; Niger Delta Region; and the border post in the North-Eastern region, notorious for illegal arms entries, facilitate easy smuggling of illegal arms into the country (Chuma-Okoro, 2013). In other words, the proximity of these countries to each other coupled with the porous nature of 
Nigeria's border inflame and perpetuate armed violence currently ragging in the nation.

\subsection{Globalisation}

Precipitating the growing proliferation of SALWs globally, and in Nigeria, is the idea of globalisation. This is a phenomenon that has not only turned the world into a microvillage, but also increased the ease of doing business within and across borders. Such businesses could be licit or illicit depending on the parties involved. Not only governments but also terrorists and other criminal groups are known to engage in arms deals worth millions of dollars. The idea of globalisation and the call for free market forces with minimum economic barriers and open trade for world development by minimising custom regulations and border control arguably promotes illicit trade in arms and easies trafficking of small arms and light weapons. Associated with this development is the faking of documents, bribing officials and concealing arms in the guise of humanitarian aids (Mallam, 2014). Among some of the Globalisation factors responsible for the proliferation of SALWs provided by Malhotra (as cited in Mallam, 2014) are the following: Political and economic integration tied with minimal restrictions on migration and human movement, which arms dealers take advantage of to transact various arms deals; banking reforms and capital mobility involving the use of emoney or e-banking that facilitate business transactions, have come handy for arms dealers as well, who launder arms sales money without easy detection by security agents; expansion of commercial airline and freight industry - making transport cheaper and easier - are instrumental to increased penetration of arms in conflict areas; in addition to airline mergers, companies, supply chains, shipping firms that have made it difficult to supervise unlawful practices in air and water; and lastly, the growth of global communication in the past two decades, increasing the ability of arms dealers to communicate internationally through the internet at relatively cheap rate.

\subsection{Corruption}

Corruption, the blanket under which all three previous factors are covered, has posed an unimaginable challenge to the efforts at tackling the proliferation of SALWs in Nigeria. Explaining this vital factor, Ayissi and Sall (2005), observed that bribery which is a major feature of corruption is a bug that has bitten even the customs officers and security agents to the extent they can be bribed by weapons dealers to look the other way, or sometimes sell government weapons to criminals.

Commenting on the causes of the proliferation of Small Arms and Light Weapons (SALWs), Yacubu (2005) reckons that they include, among others, trafficking in small arms; local arms production, and theft of arms belonging to individuals or the state. Yacubu points out some activities that encourage the proliferation of SALWs in Nigeria, including violent crime, workers' revolts, subversion, sabotage, religious crises, ethnic conflict, social agitation, micro-nationalism, insurrection and terrorism; the quest for easy profits, relatively mild punishments, the self-defence reflex and cultural practices (Yacubu, 2005).

These causes vis-à-vis the challenges posed by SALWs across the globe, and Nigeria in particular, justifies this author's position that the current national security architecture of the country needs re-jigging to better and sustainably combat the menace of SALWs proliferation and its attendant consequences.

\section{RE-STRUCTURING NIGERIA'S NATIONAL SECURITY ARCHITECTURE}

The following statements by the former Secretary-General of United Nations (UN) Koffi Anan, pointedly describes the enormous role of SALWs proliferation in exacerbating violence of devastating consequences. He states, "The death toll from SALWs dwarfs that of all other weapon systems and in most years greatly exceeds the toll of atomic bombs that devastated Hiroshima and Nagasaki. In terms of the carnage they cause, small arms, indeed, could well be described as Weapon of Mass Destruction (WMD). SALWs proliferation not merely a security issue, it is also an issue of human right and development. The proliferation of small arms sustains and exacerbates armed conflicts. It endangers peace keepers and workers. It undermines respect for international humanitarian laws. It threatens legitimate but weak government and it benefits terrorists as well as the perpetrators of organized crime" (as cited in Jacob, et al., 2019). Similarly, another scholar, while acknowledging the pervasiveness of SALW and their unprecedented impact in terms of users or handlers and the latent and manifest consequences, stressed that "The excessive and uncontrolled accumulation of small arms has led to the emergence of groups of armed individuals operating across and beyond state borders: rebel movements, private militias, terrorists, drug traffickers, arms dealers, etc. In some cases, this proliferation of armed groups undermines the authority of the state and its ability to guarantee the safety of its citizens. Everyday experience in West Africa shows that the proliferation of small arms is a catalyst for crises and armed violence and helps to destabilize governments and states, in particular as a result of the activities of subversive movements, guerrilla campaigns, terrorism, drug trafficking, civil wars and other attacks on fundamental rights and human dignity (Yacubu, 2005). He emphasized the need for West African countries to urgently put in place mechanisms to curb the prevailing trend of SALWs proliferation.

The Nigerian situation exemplifies the thought-provoking rendering by Anan, and Yacubu. However, there appears to be a lack of political will by past and present governments to combat the perennial threats posed by SALWs. Experiences have shown that despite efforts made so far to curb the menace, armed violence and other criminal activities are on the rise. How and why is this so? Perhaps, a look at the nation's current security architecture, which Arase (2018) 
describes as "largely reactive and less proactive," holds the answer.

The national security configuration of Nigeria has been critiqued as being too rigid and ineffective and jeopardizes quick decision-making and prompt action especially during emergencies as typified in the Boko Haram debacle. Thomas and Aghedo (2014) noted that Nigeria having grappled and still does, with myriad of insecurity threats such as the Niger Delta Militancy and the Boko Haram terrorism, to mention this two, the country still operates an old security structure that belies its capability to combat the ongoing security threats. This deficiency is located within the current security architecture that sees all the security agencies including the army, police and paramilitary, taking order(s) from the "top" before swinging into action even when the situation demands that swift response be followed upon receipt of intelligence report. Thus, Thomas and Aghedo (2014) contended that: "The major explanation for the upsurge in the scale of violent insecurity and the poor delivery of Nigeria's security architecture is the centralisation of security apparatus".

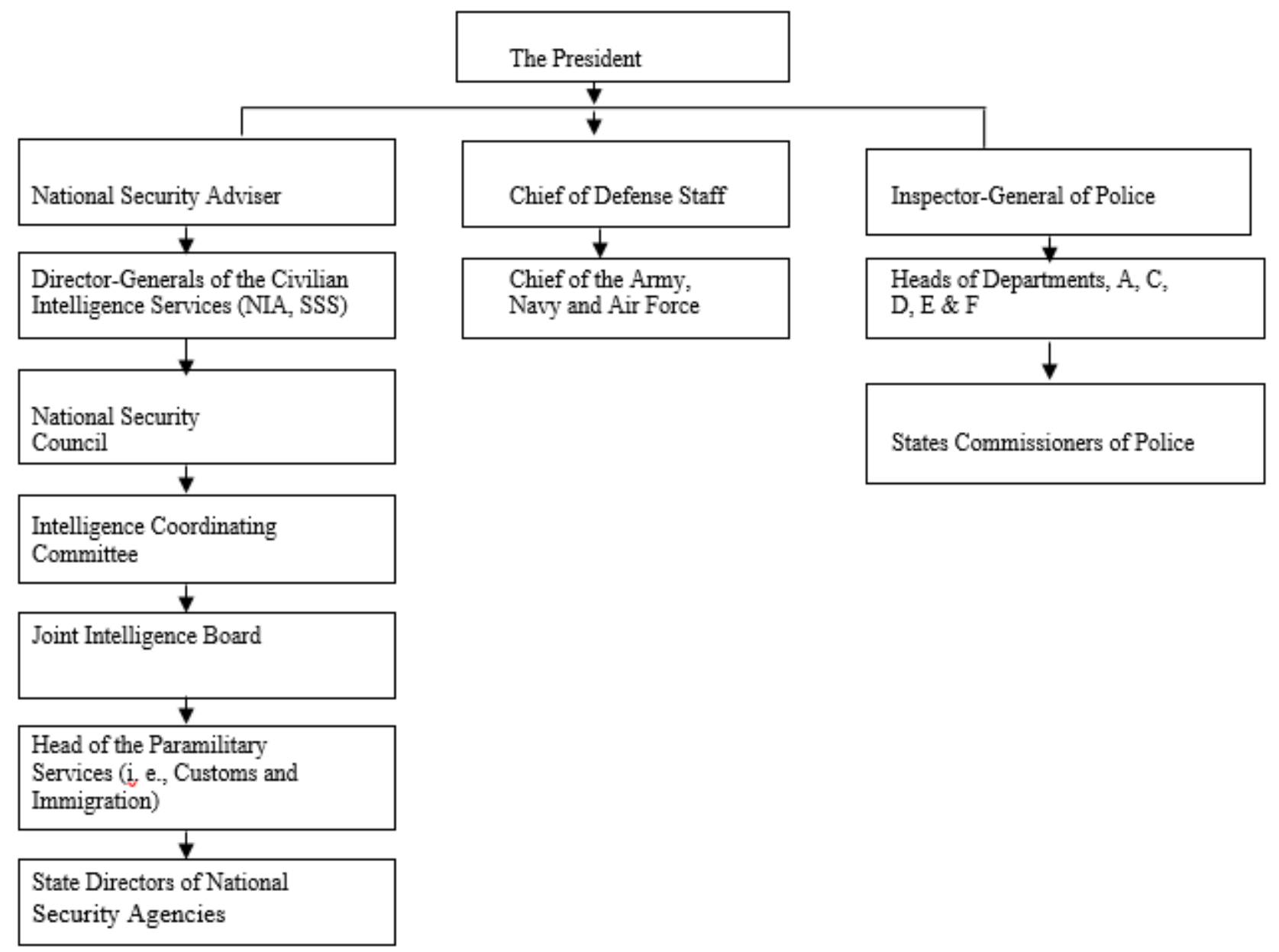

Figure 1: National Security Architecture. It shows the current security architecture of Nigeria. As the diagram clearly depicts, the system is arranged in such a way that all three security heads (National Security Adviser, Chief of Defense Staff, and Inspector General of Police) derived their power from the President and Commander-in-Chief of the Armed Forces of the Federal Republic of Nigeria, who apparently derives his authority or power from the country's constitution.

Source: Adapted from Thomas \& Aghedo (2014)

The "African Peace and Security Architecture" (APSA) of the African Union (AU) provides that "African solutions to African problems" should be pursued or encouraged. For a very long time, Africa has relied on the West for solutions to her security challenges in which she applies military tactics to tackling her internal and external security threats manifesting in various forms. In the case of Nigeria, the security challenges inlude insurgency, militancy, armed banditry, kidnapping, cattle rustling, religious conflicts, and farmers- herders conflicts, among others. The security architecture or structure of APSA encompasses the following:

i. A Policy-making body (the Peace and Security Council, PCS);

ii. A Centre for analysis and data collection (the Continental Early Warning System, CEWS);

iii. Two Military Structures (the African Standby Forces, ASF, and the Military Staff Committee, MSC); 
iv. An Advisory body of outside mediation (the Panel of the Wise); and

v. A Special fund to finance the operations (the Peace Fund)

Despite some political (in terms of external interference) and financial (in terms of logistics deployment capabilities) limitations in the way of its consolidation, the APSA remains a force to reckon with in ensuring general security and human security in the African continent, and in particular, Nigeria, if courageously adhered to. The four components are collapsed into two major complementary instruments, namely, The Peace and Security Council (PSC), and the African Standby Force (ASF). PSC represents the "decision-making body for conflict prevention, management and resolution" that serves as a mechanism of collective security and early warnings systems that should provide timely and effective response to situations of crisis and conflict in Africa, as well as propose the external intervention, should the PSC deem it necessary. The Council comprises 15 members, five of whom are elected for three-year terms.

The Main objectives of ASF are as follows:

i. Promoting peace, security and stability in Africa;

ii. The prevention of conflicts;

iii. Promoting the activities of peace-building and postconflict reconstruction;

iv. The coordination of efforts to fight terrorism;

v. The development of a common defence policy for the AU, and

vi. Strengthening of democratic practices, good governance, human rights or fundamental freedoms protection (Grasa \& Mateos, 2010).

Other details are outside the scope of this study, but they are worth giving consideration by any country in the African continent that genuinely seeks to address the issue of its national (in)security. It is recalled that the OAU (now AU) noted in its 1991 Kampala document, "Towards a Conference on Security, Stability, Development and Cooperation in Africa" that security is a holistic phenomenon comprising virtually all components of the society including economic, political and social dimensions of individuals, family, community, local and national life, such that the security of the individual citizen takes centre stage and forms the bedrock of national security.

\section{PROPOSED NATIONAL SECURITY ARCHITECTURE FOR NIGERIA FOR OPTIMAL RESULTS}

The current national security structure of the Nigerian NationState is depicted in figure 1. It shows the President and Commander-in-Chief at the helm of affairs of all the security apparatus. In other words, he alone reserves the prerogative or right to order any action that he/she deems necessary to quell

any insurrection or threat to the country's corporate existence, be it terrorism, militancy, religious crisis, armed robbery, kidnapping, cybercrime, armed banditry, and farmer/herders conflict. However, it is becoming increasing clear that this arrangement is incapable of taming the upsurge in crime and criminality in the land, which has seen hundreds of thousands of lives and property lost and destroyed by activities of terrorists, armed bandits, kidnappers, among other criminal elements, who cash in on the availability of Small and Light Weapons across the country, to kill military personnel and civilians as well as destroy property almost daily. It is, therefore, fair to suggest that the current security architecture be re-structured and re-aligned for it to address head-on the state of insecurity in the country. Hence, this study concretely and realistically proposes a two-pronged model of security: Human Security and Military Might. Emphasis should be placed on human security which sees to the provision of livelihoods such as sustainable employment for the teaming youth population, provision of access to credit facilities to interested persons to start or expand their businesses, as well ensuring that all the basic social amenities such as electricity, roads, water, hospitals are available and adequate for the use of all and sundry. What this implies is that peace-building is given priority over conflict resolution or de-escalation which usually involves the use of the militaryor armed forces to actualise. This also aligns with one of the objectives of the PSC of APSA, which is "strengthening of democratic practices, good governance, human rights or fundamental freedoms protection".

On the flip side, however, is the need to have a stand-by force comprising all the security agencies (Joint Force [JF]), which works $24 / 7$ in synergy to patrol the country's border, engage in reconnaissance operations using surveillance cameras, gather coded intelligence data from local residents, among others. As the name suggests, this special force should be given specialised training at home and abroad in military-civil relations, non-combatant but vigilant engagement. They should be schooled in international humanitarian laws and principles and other rules of engagement pertaining to armed conflicts involving civilians.

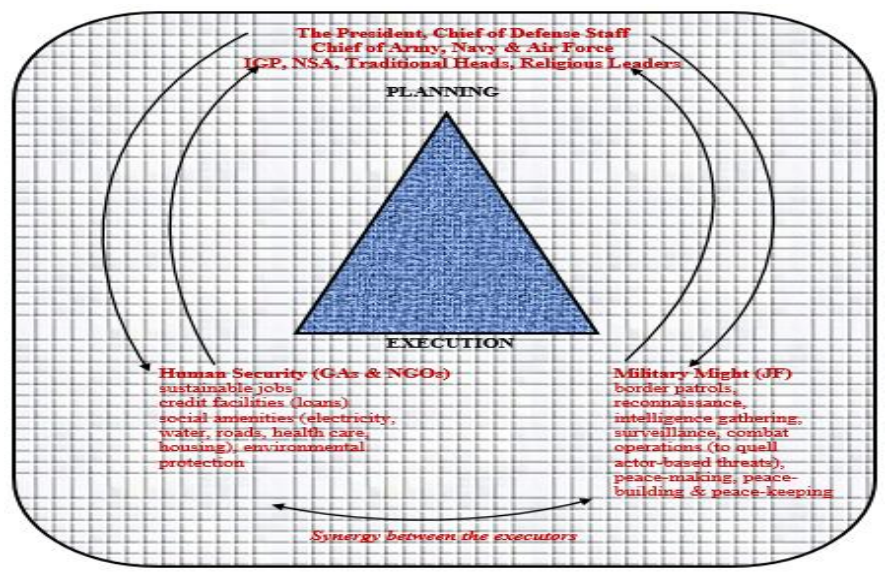

Figure 2: Proposed Nigeria's National Security Architecture

Source: Author's Concept, 2021 
Note: The downward and upward arrows indicate a feed-back mechanism between planners (policy makers) and the executors (GAs and NGOs, Military), while the single arrow at the bottom shows a synergy between the executors.

The proposed and new security architecture is one that involves a symbiotic relationship and a feed-back mechanism between the security planners and the executors; and also a cross-fertilisation of ideas between the executors. The human security component of the structure comprises collaboration between Government Agencies (GAs) and Non-Governmental Organisations (NGOs) in the execution of human security requirements or needs. While the Military Might is a Joint Force (JF) comprising all the security sectors, working in synergy to make peace, build peace and keep peace - by peaceful-soft-style or violent-hard-style - depending on the prevailing circumstances.

\section{CONCLUSION}

The study undertook an expose of Small Arms and Light Weapons proliferation (SALW) in Nigeria and its role in heightening insecurity and criminality in the land. It argued that Small Arms and Light Weapons proliferation (SALW) is a global phenomenon of the $21^{\text {st }}$ century. It noted that the trend is intractable and pervasive in the African continent and in Nigeria in particular, such that non-state actors have explored it to facilitate their nefarious criminal activities resulting in small and large scale human and material consequences. It examined Nigeria's National Security Architecture as currently constituted and argued that it has failed to address the intractability of SALWs proliferation and its attendant consequences evident in banditry, terrorism, kidnapping, and other violent crimes, leading to heightened insecurity in the country. It proposes a new national security architecture aimed at addressing all forms of security threats that plague Nigeria now and likely in the future. It further argued that such structure should be people-centred, placing premium on human security as against the traditional statecentred practice of securing the country's territory and sovereignty through military might. The paper concludes by suggesting that intelligent polices (built into the nation's security architecture) aimed at preventing the entrenchment of violence by individuals or groups, in any part of the country, is the panacea for peace and security. Such policies should have inputs from traditional rulers, religious leaders and, to a certain extent, the youth, who often form the bulk of the actors in major armed conflicts.

\section{REFERENCES}

[1] Abdullahi, I. (2015). Contextualizing the Proliferation of Small Arms and Light Weapons in Nigeria: The Untold Story. International Journal of Business and Law Research. 3(1)

[2] Agbiboa D. E. (2013). Armed Groups, Arms Proliferations and the Amnesty Program in the Niger Delta. Journal of Third World Studies, 30(2), 39-63

[3] Afolabi, M. B. (2016). The Concept of Security. Readings in Intelligence \& Security Studies, 1-11

[4] Arase, S. E. (2018). "Strengthening Internal Security Frameworks and Community Policing in Nigeria: Models, Policy Options and
Strategies". Inaugural Lecture delivered at the National Institute for Policy and Strategic Studies, Kuru-Jos on 19th February, 2018

[5] Ayissi, A \& Sall, I. (2005) (eds). Combating the Proliferation of Small Arms and Light Weapons in West Africa: Handbook for the Training of Armed and Security Forces. Geneva, Switzerland: United Nations Institute for Disarmament Research (UNIDIR)

[6] Ayuba, C. \& Okafor, G. (2015). The Role of Small Arms and Light Weapons Proliferation in African Conflicts. African Journal of Political Science and International Relations, 9(3), 76-85

[7] Baldwin, D. (1997). "The concept of security". Review of International Studies, 23, 5-26.

[8] Boutwell, J., \& Klare, M. (2001). Light Weapons and Civil Violence: Policy Options for the International Community. Paper Presented at the Proceedings of the Forty-eighth Pugwash Conference on Science and World Affairs, Jurica, Mexico, 29 September-4 O ctober 1998: The Long Roads to Peace

[9] Buzan, B. (1991). New Patterns of Global Security in the21st Century. International Affairs, 67(3), 431-451.

[10] Chelule, M. E. (2014). Proliferation of Small Arms and Light Weapons: Challenge to Development, Peace and Security in Africa. IOSR Journal Of Humanities And Social Science (IOSRJHSS) 19(5), 80-87.

[11] Chuma-Okoro, H. (2013). Proliferation of Small Arms and Light Weapons in Nigeria: Legal Implications. Law and Security in Nigeria

[12] Gofwan J. D, Ishaya, J \& Ado D. M (2019). Small Arms and Light Weapons Proliferation and Insecurity in Nigeria: Nexus and Implications for National Stability. Journal of Humanities and Social Science

[13] Grasa R., \& Mateos, O. (2010). Conflict, Peace and Security in Africa: an Assessment and New Questions After 50 Years of African Independence. Institut Català Internacional per la Pau. ICIP Working Papers

[14] Holmes, K. R. (2015). What Is National Security? The Heritage Foundation. Index of U. S. Military Strength

[15] Iloani, A., \& Sunday, S. E. (2016). "Illegal Guns Flooding Nigeria", Fuelling Violence, Daily Trust, March 142016.

[16] Jacob, D. G., Ishaya, J., \& Ado, D. M. (2019). Small Arms and Light Weapons Proliferation and Insecurity in Nigeria: Nexus and Implications for National Stability. Journal of Humanities and Social Science 24(2), 2279-0837. DOI: 10.9790/0837-2402053439

[17] Jekada, E. K. (2005). Proliferation of Small Arms and Ethnic Conflicts in Nigeria: Implication for National Security. PhD Thesis, St Clements University.

[18] Karacasulu, N. \& Uzgoren, E. (2007). Explaining Social Constructivist Contributions to Security Studies. Perceptions, Summer-Autum.

[19] Kofi, A. (2010). Millennium report to UN General Assembly (UNGA), New York, USA

[20] Mallam, B. (2014). Small Arms and Light Weapons Proliferation and its Implications for West African Regional Security. International Journal of Humanities and Social Science, 4(8), 260269

[21] Mesjasz, C. (2004). "Security as an Analytical Concept". Paper presented at the 5th Pan-European conference on International Relations, in The Hague, 9-11 September 2004

[22] Moses, J. M., \& Ngomba, J. L. (2017). Small arms and light weapons proliferation in the early 21 st century: The Nigerian case. International Journal of Development and Sustainability, 6(11), 1638-1652.

[23] Musah, A. F. (2008). Africa: The Political Economy of Small Arms and Conflicts. DPMN Bulletin, 8(1), 2

[24] Nwolise, O. B. C. (2008), "National Security and Sustainable Democracy" in Emmanuel O. O. [ed], Challenges of Sustainable Democracy in Nigeria. Ibadan: John Archers Publisher

[25] Okeke, V., \& Oji, R. (2014). The Nigerian State and the Proliferation Small Arm and Light Weapons in the Northern Part of Nigeria. Journal of Educational and Social Research, 4(1), 415. 
[26] Ola, A. A. Public Perception on Proliferation of Small Arms and Light Weapons in Abuja, Nigeria: Implications for Peace and Security. Ph.D Thesis, School of Social Sciences, University of KwaZulu-Natal, Howard College Campus, Durban.

[27] Onuoha, F. C. (2012). Small Arms and Light Weapons Proliferation and Human Security in Nigeria. Published by the African Centre for the Constructive Resolution of Dispute (ACCORD).

[28] OECD (2001). "Helping Prevent Violent Conflict". Paris: OECD

[29] Paris, R. (2001). Human Security: Paradigm Shift or Hot Air?. International Security, 26(2), 87-102

[30] Rethinking Global Security: An African Perspective? (2006) Heinrich Böll Foundation Regional Office for East Africa and Horn of Africa Forest Road

[31] Salihu, M. \& Ozden, K. (2020). The Proliferation of Small Arms and Light Weapons in the North East Nigeria: The Role of The United Nations. International Journal of Social Sciences, 4(20), 46-63

[32] Schäfer, P. J. (2013). Human and Water Security in Israel and Jordan, SpringerBriefs in Environment, Security, Development and Peace 3, DOI: 10.1007/978-3-642-29299-6_2.
[33] Sjostedt, R. (2010). Talking Threats The Social Construction of National Security in Russia and the United States. Ph.D Dissertation, Department of Peace and Conflict Research, Uppsala University

[34] Small Arms Survey (2011). The Shadow of War. New York Uiversity Press

[35] Thomas, A. N., Aghedo, I. (2014). Security Architecture and Insecurity Management: Context, Content and Challenges in Nigeria. Sokoto Journal of Social Sciences, 4(1), 22-35

[36] UNDP Human Development Report 1994. (New York: Oxford University Press).

[37] United Nations Department of Public Information (UNDPI), 2004 Report, available online at http://www.un.org/en/peacebuilding/pdf/historical/hlp_more_se cure_world.pdf

[38] Yacubu, J. G. (2005). Cooperation Among Armed Forces and Security Forces in Combating the Proliferation of Small Arms. In A. Anatole \& S. Ibrahima (Eds.), Combating the Proliferation of Small Arms and light Weapons in West Africa. Switzerland: United Nations Institute for Disarmament Research, Geneva. 